\title{
Advocacy in the Modern Age
}

\author{
John H. Martin
}

\section{INTRODUCTION}

\section{Professor Robert Burns:}

Historically, public trials have been important sources of information and crucibles or debate for some of the most important public issues that have arisen in our history: from fugitive slaves and slavery itself to labor unrest and sweatshop conditions to political radicalism in the period after the First World War and again in the sixties. We would be the much poorer in our understanding of these events without what we have learned from the public trials that illuminated them. Those trials were an important part of our national character. ${ }^{1}$

\section{Judge Patrick E. Higginbotham:}

The growing imbalance between the numbers of cases decided by trial and those settled either under the threat of trial or in mediation and arbitration generates outcomes that have gone largely unexamined. Among the most disconcerting of these outcomes are

- the potential loss of focus on the intent of the controlling law in these cases

- the perils of "private justice" in a system designed to be public and non-discriminatory

- the worrisome disconnect between trial and pre-trial phases, resulting both from an expanded discovery process and from increasingly distant and detached mediations and arbitrations. ${ }^{2}$

Partner, Thompson \& Knight LLP

1. Robert P. Burns, What Will We Lose if the Trial Vanishes?, 25-26 (Nw. Univ. Sch. of Law Scholarly Commons, Working Paper No. 5), available at http://scholarlycommons.law.northwestern. edu/cgi/viewcontent.cgi?article=1004\&context=facultyworkingpapers .

2. Patrick E. Higginbotham, The Disappearing Trial and Why We Should Care, RAND REV., Summer 2004, at 28, 30 . 


\section{Judge Royal Furgeson:}

As Roscoe Pound noted a century ago, the great challenge of the law will always be to provide stability and yet to change to meet society's needs. Our goal should be to seek a proper balance for the work of the civil jury in order to enhance its viability. At the very least, we should be guided in this effort by Aristotle's Golden Mean-avoid the extremes and find the middle path. ${ }^{3}$

\section{Judge Sam Sparks and George Butts:}

Juries not only bring community values to the process of adjudication, but they also provide a vital buffer between the allpowerful government and the individual before the court. Without juries, all decisions either imposing or relieving civil or criminal liability - whether from the executive, legislative, or judicial branchcome from people who are employees of governmental entities. No long memory or sophisticated understanding of history is required to conclude that the deposition of all forms of decision-making affecting civil and criminal rights in the government, and only in the government, is undesirable. Our founders clearly understood this and fought against it. ${ }^{4}$

\section{Professor Marc Galanter:}

In a realm of ever-proliferating legal doctrine, the opportunities for arguments and decisions about the law are multiplied while arguments and decisions become more detached from the texture of facts-at least from facts that have weathered the testing of trial. The general effects of judicial activity are derived less from a fabric of examples of contested facts and more on an admixture of doctrinal exegesis, discretionary rulings of trial judges, and the strategic calculations of the parties. Contests of interpretation replace contests of proof. Paradoxically, as legal doctrine becomes more voluminous and more elaborate, it becomes less determinative of the outcomes produced by legal institutions.

3. Royal Furgeson, Essay, Civil Jury Trials R.I.P.? Can It Actually Happen in America?, 40 St. MARY’s L.J. 795, 888 (2009) (footnotes omitted) (citing Roscoe Pound, NEW PATHS OF THE LAW 1 (1950); ARistotle, Nicomachean Ethics 27, 29 (Terence Irwin trans., 2d ed. Hackett Publ'g Co. 1999) (350 B.C.)).

4. Sam Sparks \& George Butts, Disappearing Juries and Jury Verdicts, 39 TEX. TECH L. REV. 289, 313 (2007).

5. Marc Galanter, A World Without Trials?, 2006 J. DiSP. RESOL. 7, 29 (footnotes omitted) (citing Mirjan Damaska, Structures of Authority and Comparative Criminal Procedure, 84 YALE L.J. 480, 528 (1975)). 
The above quotes are representative samples of the views of two law professors, three Texas federal judges, and one practitioner. Interestingly, during their time as practicing trial lawyers, all three judges tried many jury cases as practitioners, primarily representing business interests on the defense side. ${ }^{6}$ Texas has several jurisdictions that most would describe as "plaintiff-friendly,"7 yet these three outstanding federal judges all believe passionately in the jury system, the right to trial by jury in civil cases, and the importance of the civil jury trial to our system of jurisprudence.

\section{THERE ARE STILL MANY OPPORTUNITIES FOR LAWYERS TO BE ADVOCATES}

Excellent advocacy is still the hallmark of the great trial lawyer. Opportunities for developing and honing advocacy skills are many: discovery, motion practice, hearings, depositions, settlement negotiations, and mediation. The fact that future trials may vanish means that advocacy skills during these pretrial proceedings are more important than ever. Long gone are the days of simple, passive, fact-finding-only discovery. An unfortunate outgrowth of fewer trials has been the rise of so-called Rambo litigation, ${ }^{8}$ which has been tempered somewhat in recent years by stronger judicial control by some trial courts and by the development of aspirational creeds for lawyer conduct. Cooperation in discovery between plaintiffs and defendants really does happen, especially when adversaries know they are likely to encounter each other in future litigation. Unfortunately, in some types of litigation-such as high stakes commercial litigation-cooperation can be difficult, even impossible, to achieve, and this author believes that the judiciary needs to do a far better job of ferreting out which lawyers are being

6. The author worked on cases with all three judges before they transitioned to the bench.

7. See Daniel Fisher, Plaintiff Paradise, ForBES.COM (Aug. 19, 2009, 6:00 PM), http://www.forbes.com/forbes/2009/0907/outfront-patent-law-texas-plaintiff-paradise.html (noting that "[j]uries in the Longhorn State have a reputation for being generous" and discussing the Eastern District of Texas).

8. "Rambo litigation" is defined as "incivility between opposing attorneys in the litigation process.” Alyson Nelson, Comment, Deposition Conduct: Texas's New Discovery Rules End up Taking Another Jab at the Rambos of Litigation, 30 TEX. TECH L. REV. 1471, 1482 (1999) (citing Janeen Kerper \& Gary L. Stuart, Rambo Bites the Dust: Current Trends in Deposition Ethics, 22 J. LEGAL PROF. 103, 112 (1998)). Specifically, Rambo litigators use "obstructive practices, excessive gamesmanship tactics,... and hardball techniques.” Id. (citing PROFESSIONALISM \& ETHICS Comm., Texas Young Lawyers Ass’n, TeXas Lawyers’ Professional Ethics 14-6 (3d ed. 1997)). 
unreasonable when it comes to discovery. There is no substitute for hands-on case management by the trial judge.

\section{A. Advocacy in Developing Your Case}

\section{Learn the Facts FIRST.}

Younger lawyers often dwell on esoteric and fascinating legal issues without fully grasping the key facts of the case. It is essential in every case for all lawyers involved to know the facts. While this seems obvious and basic, all too often this is not what happens. It is important to conduct client and witness interviews at the outset and obtain information from publicly available third party sources. It is also important early in every case to identify and develop a working knowledge of the key documents. Even in the most complex cases, the key documents are often relatively few in number, and it is critical that the entire trial team be intimately familiar with them.

2. After Mastering the Facts, Learn the Law and Apply it to those Facts.

The first step in learning the law and applying it to the facts of the case should be the preparation of a jury charge. This is often left to the last minute when the final pretrial order is due. Unless the case presents very simple and straightforward fact issues, however, it is critically important for every lawyer working on the case to understand what questions the court will ask the jury to answer, and what instructions and definitions the charge will contain. Then the discovery plan can be tailored around the jury charge, and time will not be wasted running down rabbit trails that lead to nowhere. Search for articles and briefs of opposing counsel in previous cases, and diligently research prior testimony and writings of opposing experts-and those of your own experts-because that's what your opponent will be doing. Pay attention to who authored the opinions you are citing in your briefs. It's always good to know if you are citing the judge's own opinion, and that certainly can avoid embarrassing situations at oral argument.

3. Develop the Theme of Your Case-_"This Is a Case About ....”

As soon as the advocate masters the facts and the applicable law, developing the theme of the case will be the pathway to everything she 
does in the case and is the lens through which she should view the case from that point forward. Try to come up with a powerful one-sentence statement of what the case is about. Develop several, and try them out on your colleagues, your support staff, your spouse or significant other, and even your children. Once you develop your basic theme, try to identify three to five "buckets" into which all your facts and legal arguments fit. Be flexible as the case goes forward. The theme may change somewhat, especially on the defense side, and facts and legal arguments may jump from one bucket to the next. The increasing use of jury research and mock trials often leads to changes in how the case will be developed and tried, and it is essential that the advocate remain flexible.

\section{B. Advocacy in Discovery: Focus on Your Theme}

In nearly every case there are fact issues you believe you can win and others that likely will prove more difficult. Try to frame the issues in your case around the issues you can win. Take the initiative, especially if you are on the defense side, and try to frame the case debate around your strongest issues. Sometimes this can mean framing the case around an issue that may be much more complex than others, but focus on issues that you can win. For example, in defending a medicalmalpractice wrongful-death case, the negligence facts may be very simple, but you know that a jury is likely to find that the medical provider was negligent. On the other hand, the issue of whether the negligent conduct proximately caused the patient's death is medically complex, but readily winnable through expert testimony and the testimony of treating physicians. While it might be tempting to try to defend the case on the easy-to-understand negligence issue, your chances of winning the case might be better if you gloss over that issue with the jury and focus them on the more complex, but winnable, proximate cause issue.

Develop an aggressive discovery plan, but keep in mind the proportionality requirements of the rules and try to be cost-effective and efficient in discovery. Young lawyers should be trained to understand how depositions are actually used at trial, and why shorter depositions sometimes are far more effective than long ones. Defendants should be proactive and obtain the discovery they need, rather than simply reacting to the plaintiff's discovery demands. Oral depositions are the lawyer's best chance to excel at advocacy during discovery. You should carefully analyze whether the oral depositions you take should be primarily for 
discovery or used to convince your opponent, mediators, and the court of your position. Usually the right balance is somewhere in between the two extremes. If your case is one in which you expect the trial will not vanish, be careful in deposing experts. Many experts are paid professionals who are very skilled at their craft of testifying, and often you are better off keeping your powder dry and saving some of your best lines of examination for trial instead of educating them at deposition.

\section{Advocacy Through Your Own Experts}

Advocates on both sides of the case often need experts to explain their side of the case to the jury in clear and understandable terms. At the beginning of the case, lawyers should determine what experts, if any, will be needed, and they should be retained as early as possible. Experts can aid the lawyer in examining the opposing experts and developing case themes.

Some experts don't do their homework before deposition, so it is important to have one or more preparation sessions to make sure your expert really knows the facts of the case almost as well as the lawyers do. If your expert doesn't know the case as well as the opposing lawyer, the expert is going to be in deep trouble at deposition and trial.

Be mindful of the 2010 amendments to Rule 26 of the Federal Rules of Civil Procedure (FRCP) with regard to disclosure of communications between expert and lawyer. ${ }^{9}$ If you are in state court, consider stipulating to apply the provisions of the 2010 amendments, because it can save a tremendous amount of expense.

\section{Advocacy in Motion Practice}

Before filing a motion, decide what your goals are in filing it. Do you really expect the court to grant the relief you are requesting? Or are you trying to educate the court, and your opponent, of the strength of your legal position? If you are fortunate enough to be in a jurisdiction that conducts oral hearings on motions, take full advantage of the oral argument and let the court know what the key issue is within the first sixty to ninety seconds of your argument. Make the argument as simple as possible and group similar issues, especially when arguing a discovery

9. In 2010, FRCP 26(b)(4) was amended to "provide work-product protection against discovery regarding draft expert disclosures or reports and... communications between expert witnesses and counsel.” FED. R. CIV. P. 26 committee note (2010 amendment). 
motion. Don't just read or summarize the motion papers, but make your best points early, clearly and quickly, and be directly responsive to any questions posed by the court.

Develop a strategy for the timing of filing dispositive motions. All too often, such motions are filed on the deadline date, when the factual development necessary to file a motion occurred much earlier. This author believes that dispositive motions have a far better chance of success when filed early in the case. Filing early signals to the court that there really aren't any disputed fact issues that need to be resolved and that the issue is purely one that the court needs to decide.

\section{E. Advocacy in Settlement Negotiations}

The reality today is that most trials do vanish, so advocacy in settlement negotiations is critically important. In many jurisdictions, nearly every civil case goes through some sort of ADR process, such as mediation. ${ }^{10}$ At mediation, you should know the case-both facts and law-better than your opponent. Some mediators have abandoned the practice of having an opening general session with all parties present unless one side or the other insists on having one. Don't wait until you are at the mediator's office to decide your position on this issue; discuss it fully with your client, and assess the pros and cons of having an opening session. If there is going to be an opening session, decide in advance what you will and will not say, and whether you will use a PowerPoint or similar presentation to present your case. Most importantly, at mediation do your best to convince the mediator and your opponent that this is a case in which the trial may not vanish, and how much you look forward to the opportunity of presenting your side of the case to the jury.

\section{WHAT CAN THE YOUNG LAWYER DO?}

The challenge of getting courtroom experience for young lawyers has never been greater, but there are ways for them to gain invaluable experience. Young lawyers should take the time to go to court and observe outstanding trial lawyers perform their craft. More seasoned lawyers can benefit from observation as well. Several years ago, this author-who practices extensively in the area of aviation law-learned

10. See Deborah R. Hensler, Our Courts, Ourselves: How the Alternative Dispute Resolution Movement Is Re-Shaping Our Legal System, 108 PENN ST. L. REV. 165, 167 (2003). 
that two of the most outstanding plaintiffs' aviation lawyers and a preeminent aviation defense lawyer were about to argue their case to a jury, so he spent the better part of a day simply observing these masterful advocates perform their craft.

Young lawyers should seek out opportunities and volunteer to attend trials, court hearings, and depositions, even if-heaven forbid-the time will not be billable.

Young lawyers should find mentors both inside and outside their firms. Becoming active in legal organizations, Inns of Court, and law school alumni associations is a good way to find mentors. Young lawyers can also obtain valuable experience through pro bono efforts and by attending some of the several outstanding trial academy programs, such as the one conducted annually by the International Association of Defense Counsel.

\section{CONCLUSION}

Even in the age of the vanishing trial, lawyers still must be zealous advocates for their clients, and there are still many opportunities to do so. This author believes the number of civil jury trials may actually increase in the years to come. Many involved in the procedural rulemaking process have come to recognize that civil litigation takes too long and costs too much. Efforts are being made to streamline the discovery rules, both at the federal level and in many state jurisdictions. ${ }^{11}$ The cost of discovery has grown exponentially ${ }^{12}$ and far too many cases are resolved based on cost considerations rather than the merits of the dispute. Through creative rulemaking that requires proportionality in discovery and more hands-on discovery management by trial judges, perhaps some of the trials that vanish today will reappear.

11. See, e.g., 2011 Civil Rules Comments, U.S. CTS., http://www.uscourts.gov/RulesAnd Policies/rules/archives/archived-rules-comments/civil-rules-comments/2011-civil-rules-

comments.aspx (last visited Jan. 28, 2013) (listing comments from various interested parties on proposed FRCP amendments).

12. See John H. Beisner, Discovering a Better Way: The Need for Effective Civil Litigation Reform, 60 DUKE L.J. 547, 549 (2010) (noting that "discovery costs now comprise between 50 and 90 percent of the total litigation costs in a case” (citing H.R. REP. No. 104-369, at 37 (1995) (Conf. Rep.); Thomas E. Willging et al., An Empirical Study of Discovery and Disclosure Practice Under the 1993 Federal Rule Amendments, 39 B.C. L. REV. 525, 547-48 \& tbl.4 (1997); Judicial Conference Adopts Rules Changes, Confronts Projected Budget Shortfalls, THIRD BRANCH, Oct. 1999, at 2-3)). 